\title{
HUBUNGAN PENGETAHUAN PERAWAT DENGAN KEPATUHANMENCUCI TANGAN BERDASARKAN STANDAR OPERASIONAL PROSEDUR DI RUANG ICU DAN RUANG HCU SARAF RUMAH SAKIT UMUM JAYAPURA
}

\author{
Rukiah Sembiring1, Puji Rahayu², Connie L. Todingbua ${ }^{3}$ \\ ${ }^{1)}$ Rumah Sakit Umum Daerah Jayapura \\ ${ }^{2)}$ Rumah Sakit Umum Daerah Kabupaten Jayapura \\ ${ }^{3)}$ Prodi Keperawatan STIKES Jayapura \\ email: ajirahayu03@gmail.com
}

\begin{abstract}
ABSTRAK
Latar Belakang: Mencuci tangan adalah proses membuang kotoran dan debu secara mekanis dari kulit kedua belah tangan dengan memakain sabun atau air. Tujuan cuci tangan adalah untuk menghilangkan kotoran dan debu secara mekanis daari permukaan kulit dan mengurangi jumlah mikroorganisme. Tujuan Penelitian: Mengetahui hubungan pengetahuan perawat dengan kepatuhan mencuci tangan berdasarkan standar operasional prosedur di ruang ICU dan ruang HCU Saraf RSUD Jayapura. Metode Penelitian: adalah metode deskriptif korelasional. Banyaknya jumlah sampel dalam penelitian ini menggunakan total sampel yaitu 35 responden dengan criteria inklusi dan ekslusi. Analisis data berdasarkan presentase dan dideskripsikan dalam table distribusi frekuensi. Hasil: analisis korelasi Spearman memiliki nilai $r_{s}=0.717$, hal ini menunjukkan adanya keeratan hubungan antara pengetahuan perawat dengan kepatuhan. Tanda positif pada nilai $r_{s}$ menunjukkan bahwa pola hubungan linier, artinya semakin meningkat pengetahuan perawat akan disertai dengan meningkatnya kepatuhan. Nilai Sig.(2-tailed)=0.000 menunjukkan adanya kemaknaan hubungan antara dua variabel tersebut. Kesimpulan: Cuci tangan merupakan suatu tindakan kecil yang harus dilakukan sesudah dan sebelum melakukan tindakan keperawatan. Mencuci tangan adalah membersihkan tangan dari segala kotoran, dimulai dari ujung jari sampai siku dan lengan dengan cara tertentu sesuai kebutuhan. Perilaku cuci tangan adalah salah satu bentuk kebersihan diri yang penting.
\end{abstract}

Kata Kunci : Pengetahuan, Kepatuhan, Cuci tangan

\begin{abstract}
Background: Hand washing is the process of removing dirt and dust mechanically from the skin of both hands by using soap or water. The purpose of hand washing is to remove dirt and dust mechanically from the surface of the skin and reduce the number of microorganisms. Objective: To find out the relationship between knowledge of nurses and handwashing compliance based on standard operating procedures in the ICU room and the HCU Room at the Jayapura Public Hospital. Research Methods: is a descriptive correlational method The number of samples in this study used a total sample of 35 respondents with inclusion and exclusion criteria. Analysis of data based on percentages and described in the frequency distribution table. Results: Spearman correlation analysis has a value of $r s=0.717$, this indicates the closeness of the relationship between knowledge of nurses and compliance. A positive sign on the value of $r$ indicates that the pattern of linear relationships, meaning that increasing nurse knowledge will be accompanied by increased compliance. The Sig (2-tailed) value $=0.000$ indicates the significance of the relationship between the two variables. Conclusion: Hand washing is a small action that must be done after and before carrying out nursing actions. Washing your hands is cleaning your hands from all dirt, starting from your fingertips to your elbows and arms in certain ways as needed. Handwashing behavior is an important form of personal hygiene.
\end{abstract}

Keywords:Knowledge,Compliance, Washhands 


\section{PENDAHULUAN}

Standar mutu pelayanan kesehatan sebuah rumah sakit akan selalu terkait dengan struktur, proses, dan outcome sistem pelayanan rumah sakit tersebut. Standar mutu pelayanan kesehatan rumah sakit juga dapat dikaji dari tingkat pemanfaatan sarana pelayanan oleh masyarakat, mutu pelayanan, dan tingkat efisiensi rumah sakit. Infeksi nosokomial banyak terjadi di seluruh dunia dengan kejadian terbanyak di negara miskin dan negara yang sedang berkembang karena penyakit-penyakit infeksi masih menjadi penyebab utama (Wulandari, 2010).

HAIs (Health Care Associated Infection) adalah infeksi yang terjadi akibat pelayanan kesehatan. Kriteria HAIs adalah infeksi yang terjadi atau yang didapat dari rumah sakit atau fasilitas pelayanan kesehatan setelah 48 jam atau lebih, dan bukan merupakan dampak dari tanda dan gejala infeksi sebelumnya. Infeksi ini dapat menambah biaya perawatan pasien dan juga akan memperpanjang perawatan di rumah sakit serta menimbulkan biaya untuk uji diagnostik dan pengobatan lain (Puspasari, 2015).

Mencuci tangan adalah proses membuang kotoran dan debu secara mekanis dari kulit kedua belah tangan dengan memakain sabun atau air. Tujuan cuci tangan adalah untuk menghilangkan kotoran dan debu secara mekanis daari permukaan kulit dan mengurangi jumlah mikroorganisme (Tietjen, 2010). Cuci tangan (hand hygiene) harus dilakukan dengan benar sebelum dan sesudah melakukan tindakan perawatan meskipun memakai sarung tangan atau alat pelindung lain untuk menghilangkan atau mengurangi mikroorganisme yang ada di tangan, sehingga penyebaran penyakit dapat dikurangi dan lingkungan terjaga dari infeksi. Indikasi cuci tangan harus dilakukan pada saat yang diantisipasi akan terjadi perpindahan kuman melalui tangan, yaitu sebelum melakukan tindakan yang dimungkinkan terjadi pencemaran dan setelah melakukan tindakan yang dimungkinkan terjadi pencemaran (Depkes RI, 2010).

Teknik yang paling dasar dalam pencegahan dan pengontrolan penularan infeksi adalah dengan cara cuci tangan. Mencuci tangan tangan secara tepat merupakan salah satu cara yang dapat dilakukan untuk menurunkan insiden HAIs. Langkah sederhana namun efektif dalam melindungi pasien dari kejadian infeksi adalah cuci tangan (William, dkk, 2012). Namun, penerapan cuci tangan yang sesuai prosedur oleh petugas kesehatan masih rendah. Secara umum, tingkat pemenuhan cuci tangan sesuai prosedur oleh petugas kesehatan di bawah 50 persen (Mani, dkk, 2010)

Pengetahuan merupakan salah satu dari ketiga komponen pembentuk sikap yaitu komponen kognitif. Dalam teori Rosenberg, pengetahuan dan sikap berhubungan secara konsisten. Bila komponen kognitif (pengetahuan) berubah, maka akan diikuti perubahan sikap. Berdasarkan teori tersebut dapat disimpulkan bahwa, pengetahuan seseorang seharusnya berhubungan dengan sikapnya. Secara garis besar pengetahuan responden sudah cukup baik dalam hal pencegahan infeksi yang dilakukan sehari-hari. Begitupun dengan sikap responden yang mendukung dalam aspek pencegahan infeksi tersebut. Hal ini dapat disimpulkan bahwa, pengetahuan yang baik akan memicu sikap yang baik juga, begitupun sebaliknya (Setiana, 2011).

Banyak dijumpai tindakan salah yang sering dilakukan perawat seperti jarang mencuci tangan sebelum melakukan tindakan. Kadang kala ada juga perawat yang menggunakan sarung tangan dan lupa menggantinya sewaktu memeriksa satu pasien ke pasien lain, atau dari satu bagian tubuh kebagian tubuh lainya, serta kebiasaan yang lupa memakai alat pelindung diri dalam memberikan asuhan keperawatan. Cuci tangan menjadi salah satu langkah yang efektif untuk memutuskan rantai transmisi infeksi, sehingga infeksi nosokomial Hals dapat berkurang. Pencegahan dan pengendalian infeksi mutlak harus dilakukan oleh perawat, dokter, dan seluruh orang yang terlibat dalam perawatan pasien. Salah satu komponen standar kewaspadaan dan usaha menurunkan infeksi nosokomial adalah menggunakan secara WHO panduan kebersihan tangan yang benar dan mengimplementasikan secara efektif (Saragih \& Rumpea, 2010).

Data dari WHO tahun 2011 kepatuhan mencuci tangan lima momen di Amerika Serikat 50\% sedangkan di Australia 65 persen dan di Indonesia data Riset Kesehatan Dasar (RISKESDAS) tahun 2007 prevalensi nasional berperilaku benar dalam mencuci tangan adalah 23.2 persen . Sedangkan di RSUD Jayapura kepatuhan mencuci tangan 40\% Praktek mencuci tangan oleh perawat yang direkomendasikan adalah lima moment yaitu sebelum kontak dengan pasien, sebelum melakukan tindakan aseptik, setelah 
kontak dengan pasien, setelah kontak dengan cairantubuh pasien, setelah kontak dengan peralatan lingkungan sekitar pasien. Mencuci tangan yang benar adalah mencuci tangan yang telah dilaksanakan dengan prosedur yang benar dengan enam langkah yang secara berurutan. Tujuan dilakukannya mencuci tangan adalah mengangkat mikroorganisme yang ada di tangan, mencegah infeksi silang (cross infection), menjaga kondisi steril, melindungi diri dan pasien dari infeksi, memberikan perasaan segar dan bersih (Sari, 2017). Praktek cuci tangan oleh perawat yang direkomendasikan adalah lima moment yaitu sebelum kontak dengan pasien, sebelum melakukan tindakan aseptik, setelah kontak dengan pasien, setelah kontak dengan cairan tubuh pasien, setelah kontak dengan peralatan lingkungan sekitar pasien. Cuci tangan yang benar adalah cuci tangan yang telah dilaksanakan dengan prosedur yang benar dengan enam langkah menurut WHO yang dilakukan secara berurutan. Tujuan dilakukannya cuci tangan adalah mengangkat mikroorganisme yang ada di tangan, mencegah infeksi silang (cross infection), menjaga kondisi steril, melindungi diri dan pasien dari infeksi, memberikan perasaan segar dan bersih (Sari, 2017).

Pelaksanaan cuci tangan yang baik dan benar perlu dilakukan dengan keinginan dari perawat itu sendiri yang sering disebut motivasi. Motivasi yang dimiliki dapat meningkatkan kepatuhan dalam melaksanakan enam langkah cuci tangan yang baik dan benar. Motivasi adalah suatu dorongan atau keinginan dalam diri manusia yang menyebabkan tangan berupa wastafel yang dilengkapi sabun antiseptik maupun dengan teknik handcsrub, dan pengetahuan tentang prosedur cuci tangan yang benar semakin diperbaiki dan ditingkatkan melalui studi dan kerjasama dengan berbagai pihak, sedangkan berdasarkan hasil pengamatan awal peneliti di Ruang ICU dan Ruang HCU Saraf RSUD Jayapura pada perawat jaga yang banyak intensitas melakukan perawatan pada pasien didapatkan kurangya kepatuhan perawat untuk melakukan cuci tangan enam langkah yang benar. Padahal diruang tersebut untuk fasilitas gambar enam langkah dan prosedur cuci tangan sudah tersedia dengan baik. individu melakukan sesuatu untuk memenuhi kebutuhannya. Dalam meningkatkan upaya pencegahan dan pengendalian infeksi nosokomial diperlukan perilaku yang mendukung menuju perubahan yang lebih baik dalam perilaku kepatuhan mencuci tangan khususnya bagi seorang perawat sesuai dengan prosedur yang telah ditetapkan (Septiari, 2012).

Menurut Notoatmodjo (2010), penyebab perilaku dipengaruhi oleh tiga faktor yaitu faktor predisposisi (predisposting factor), faktor pemungkin (enabling factor), dan faktor penguat (reinforcing factor). Faktor predisposing mencakup pengetahuan, sikap, keyakinan dan nilai.

Di Indonesia data Riset kesehatan dasar tahun 2007 prevalensi nasional berperilaku benar dalam mencuci tangan adalah 23.2 persen. .data di Rumah Sakit Umum Jayapura didapatkan kepatuhan mencuci tangan 40\%. RSUD Jayapura telah membuat prosedur tetap cuci tangan yang benar, menyediakan sarana cuci

Berdasarkan studi pendahuluan yang dilakukan oleh penulis yang dilakukan di Ruang ICU dan Ruang HCU Saraf RSUD Jayapura dengan teknik wawancara dan observasi didapatkan perawat yang cuci tangan lima moment masih dalam kategori kurang, meliputi perawat tidak melakukan cuci tangan sebelum kontak dengan pasien, kontak dengan lingkungan sekitar pasien, sebelum melakukan tindakan aseptik.

Dalam meningkatkan upaya pencegahan dan pengendalian infeksi nosokomial diperlukan perilaku yang mendukung menuju perubahan yang lebih baik, khususnya bagi seorang perawat. Berdasarkan latar belakang tersebut maka peneliti tertarik untuk melakukan penelitian tentang hubungan pengetahuan perawat terhadap infeksi nosokomial dengan kepatuhan mencuci tangan berdasarkan standar operasional prosedur di Ruang ICU dan Ruang HCU Saraf RSUD Jayapura.

\section{METODE PENELITIAN}

Penelitian ini menggunakan metode penelitian deskriptif korelasional.. Waktu penelitian dilaksanakan pada November 2018- Agustus 2019. Populasi adalah perawat yang berdinas di ruang ICU dan Ruang HCU saraf berjumlah 35 perawat yang melakukan kepatuhan mencuci tangan derdasarkan standar operasional prosedur. Teknik pengambilan sampel menggunakan teknik total sampling dengan jumlah 35 responden. Analisa data dalam penelitian ini menggunakan analisa univariat dalam bentuk frekuensi dan bivariate dengan menggunakan uji Spearman Rank.

\section{HASIL PENELITIAN}

Penelitian ini dilaksanakan dengan tujuan mengetahui hubungan pengetahuan perawat dengan kepatuhan mencuci tangan berdasarkan standar operasional prosedur di ruang ICU dan ruang HCU 
Rukiah Sembiring : Hubungan Pengetahuan Perawat Dengan KepatuhanMencuci Tangan Berdasarkan Standar Operasional Prosedur Di Ruang Icu Dan Ruang Hcu Saraf Rumah Sakit Umum Jayapura

saraf rumah sakit umum jayapura

1. Karakteristik responden

\begin{tabular}{|c|c|c|}
\hline \multicolumn{3}{|c|}{ Tabel 1. Usia } \\
\hline Kriteria & Frekuensi & $(\%)$ \\
\hline \multicolumn{3}{|l|}{ Umur } \\
\hline 17-25 tahun & 3 & 8.6 \\
\hline 26-35 tahun & 13 & 37.1 \\
\hline 36-45 tahun & 11 & 31.4 \\
\hline 46-55 tahun & 8 & 22.9 \\
\hline Total & 35 & 100.0 \\
\hline \multicolumn{3}{|c|}{ Tabel 4. Lama Kerja } \\
\hline Kriteria & Frekuensi & $(\%)$ \\
\hline
\end{tabular}

Berdasarkan tabel 1 pengelompokan usia di urutkan berdasarkan Departemen Kesehatan tahun 2009. Dari 35 respoden yang diteliti, 3 orang atau $8.6 \%$ berusia $17-25$ tahun, 13 orang atau $37.1 \%$ berusia $26-35$ tahun, 11 orang atau $31.4 \%$ berusia 36-45 tahun, dan 8 orang atau $22.9 \%$ berusia $46-55$ tahun. Hal ini menunjukkan bahwa sebagian besar responden berada pada usia produktif yaitu 26-35 tahun, dan yang paling sedikit berada pada usia 1725 tahun.

Tabel 2. Jenis Kelamin

\begin{tabular}{c|c|c}
\hline Kriteria & Frekuensi & $(\boldsymbol{\%})$ \\
\hline Jenis Kelamin & & \\
Laki-laki & 13 & 37.1 \\
Perempuan & 22 & 62.9 \\
Total & 35 & 100.0 \\
\hline
\end{tabular}

Kriteria responden berdasarkan jenis kelamin. Dari 35 responden yang diteliti, 13 orang atau $37.1 \%$ diantaranya berjenis kelamin laki-laki, dan 22 orang atau $62.9 \%$ diantaranya berjenis kelamin perempuan. Hal ini menunjukkan bahwa sebagian besar responden berjenis kelamin perempuan.

Tabel 3. Pendidikan

\begin{tabular}{c|c|c}
\hline Kriteria & Frekuensi & $(\mathbf{\% )}$ \\
\hline Pendidikan & & \\
D3 & 21 & 60.0 \\
S1 & 14 & 40.0 \\
Total & 35 & 100.0 \\
\hline
\end{tabular}

Kriteria responden berdasarkan tingkat pendidikan. Dari 35 responden yang diteliti, 21 orang atau $60.0 \%$ berpendidikan D3, dan 14 orang atau $40.0 \%$ berpendidikan S1. Hal ini menunjukkan bahwa sebagian besar responden berpendidikan D3, dan sebagian kecil responden berpendidikan S1.

\begin{tabular}{c|c|c}
\hline Lama Kerja & & \\
1-5 Tahun & 14 & 40.0 \\
$>5$ Tahun & 21 & 60.0 \\
Total & 35 & 100.0 \\
\hline
\end{tabular}

Kriteria responden berdasarkan lama kerja. Dari 35 responden yang diteliti, 14 orang atau $40.0 \%$ telah bekerja selama $1-5$ tahun, dan 21 orang atau $60.0 \%$ telah bekerja selama lebih dari 5 tahun. Hal ini menunjukkan bahwa sebagian besar responden telah lebih dari 5 tahun bekerja mengabdikan diri di RSUD Jayapura..

Tabel 5. Pengetahuan Perawat

\begin{tabular}{c|c|c}
\hline Kriteria & Frekuensi & $(\boldsymbol{\%})$ \\
\hline Pengetahuan & & \\
Baik & 33 & 94.3 \\
Cukup & 1 & 2.9 \\
Kurang & 1 & 2.9 \\
Total & 35 & 100.0 \\
\hline
\end{tabular}

Pada tabel 5 di atas menggambarkan pengetahuan perawat. Dari 35 responden yang diteliti, 33 orang atau $94.3 \%$ memiliki pengetahuan baik, 1 orang atau $2.9 \%$ memiliki pengetahuan cukup, dan 1 orang atau $2.9 \%$ memiliki pengetahuan kurang. Hal ini menunjukkan bahwa hampir seluruh responden memiliki pengetahuan baik, sedangkan hanya sebagian kecil perawat yang memiliki pengetahuan cukup dan kurang.

Tabel 6. Kepatuhan Perawat

\begin{tabular}{l|c|c}
\hline Kriteria & Frekuensi & $\mathbf{( \% )}$ \\
\hline Kepatuhan & & \\
Patuh & 34 & 97.1 \\
Tidak Patuh & 1 & 2.9 \\
Total & 35 & 100.0 \\
\hline
\end{tabular}

Pada tabel 6 di atas menggambarkan kepatuhan perawat dalam mencuci tangan. Dari 35 responden yang diteliti, 34 orang atau $97.1 \%$ patuh, dan 1 orang atau $2.9 \%$ tidak patuh. Hasil ini menunjukkan bahwa hampir seluruh responden patuh dalam melakukan pencegahan infeksi nosokomial dengan cara mencuci tangan.

\section{Analisa Bivariat}

Dalam Analisa bivariat ini, peneliti menggunakan uji korelasi Spearman Rho untuk mengetahui hubungan pengetahuan perawat dengan kepatuhan di ruang ICU dan ruang HCU Saraf Rumah Sakit Umum Daerah Jayapura. Hasil 
korelasi Spearman dapat dilihat pada tabel dibawah ini:

Tabel 7. Hubungan Penghetahuan Perawat dengan Kepatuhan

\begin{tabular}{c|c|c|c}
\hline Variabel & $\begin{array}{c}\text { Spearman } \\
\text { Correlation }\left(\mathrm{r}_{\mathrm{s}}\right)\end{array}$ & Sig. (2-tailed) & Keterangan \\
\hline $\begin{array}{c}\text { Pengetahuan Perawat- } \\
\text { Kepatuhan }\end{array}$ & 0.717 & 0.000 & Keeratan kuat \\
\hline $\mathrm{N}$ & 35 & Jumlah & \\
\hline$\ldots$ & $\ldots$
\end{tabular}

Tabel 7. Hubungan Penghetahuan Perawat dengan Kepatuhan Dari tabel 7 diketahui hasil analisis korelasi Spearman memiliki nilai $\mathrm{r}_{\mathrm{s}}=0.717$, hal ini menunjukkan adanya keeratan hubungan antara pengetahuan perawat dengan kepatuhan. Tanda positif pada nilai $r_{s}$ menunjukkan bahwa pola hubungan linier, artinya semakin meningkat pengetahuan perawat akan disertai dengan meningkatnya kepatuhan. Nilai Sig.(2-tailed) $=0.000$ menunjukkan adanya kemaknaan hubungan antara dua variabel tersebut.

\section{PEMBAHASAN}

\section{Analisa Univariat}

Pada tabel 1 pengelompokan usia diurutkan berdasarkan Departemen Kesehatan tahun 2009. Dari 35 respoden yang diteliti, 3 orang atau $8.6 \%$ berusia $17-25$ tahun, 13 orang atau $37.1 \%$ berusia 26-35 tahun, 11 orang atau $31.4 \%$ berusia $36-45$ tahun, dan 8 orang atau $22.9 \%$ berusia $46-55$ tahun. Hal ini menunjukkan bahwa sebagian besar responden berada pada usia produktif yaitu 26-35 tahun, dan yang paling sedikit berada pada usia 17-25 tahun. Usia berdasarkan WHO meliputi usia pertengahan (middle age) ialah kelompok usia 45 sampai 59 tahun, lanjut usia (elderly) antara 60 sampai 74 tahun, lanjut usia tua (old) antara 75 sampai 90 tahun dan usia sangat tua (very old) usia diatas 90 tahun.

Batas usia berdasarkan Depkes RI (2009), yaitu masa balita pada umur 0-5 tahun, masa kanak-kanak pada umur 5-11 tahun, masa remaja awal pada umur 12-16 tahun, masa remaja akhir pada umur 17-25 tahun, masa dewasa awal pada umur 26-35 tahun, masa dewasa akhir pada umur 36-45 tahun, masa lansia awal pada umur 46-55 tahun, masa lansia akhir pada umur 56-65 tahun dan masa manula pada umur 65-sampai atas.

Dengan bertambahnya umur seseorang akan terjadi perubahan aspek fisik dan psikologi (mental), dimana aspek psikologis ini taraf berfikir seseorang semakin matang dan dewasa. Usia seseorang akan mempengaruhi daya tangkap dan pola pikir seseorang terhadap informasi yang didapatkan ataupun yang diberikan. Semakin bertambahnya usia maka daya tanggap dan pola seseorang semakin berkembang dan lebih banyak mendapatkan informasi, selain itu juga semakin cukup umur dan tingkat kematangan serat kekuatan seseorang akan lebih matang dalam menerima informasi serta lebih profesional dalam berfikir dan berkerja (Wawan \& Dewi, 2011).

Kriteria responden berdasarkan jenis kelamin. Dari 35 responden yang diteliti, 13 orang atau $37.1 \%$ diantaranya berjenis kelamin laki-laki, dan 22 orang atau $62.9 \%$ diantaranya berjenis kelamin perempuan. Hal ini menunjukkan bahwa sebagian besar responden berjenis kelamin perempuan sesuai dengan data yang ada di Indonesia yaitu perbandingan jumlah perawat lebih banyak perawat berjenis kelamin perempuan dari pada perawat berjenis kelamin laki-laki. Tetapi ada juga rumah sakit yang memiliki perawat perempuan dan lakilaki yang sama jumlahnya hal ini dikarena pihak rumah sakit tersebut menyadari betul bahwa masih membutuhkan tenaga laki-laki.

Kriteria responden berdasarkan tingkat pendidikan. Dari 35 responden yang diteliti, 21 orang atau $60.0 \%$ berpendidikan D3, dan 14 orang atau $40.0 \%$ berpendidikan S1. Hal ini menunjukkan bahwa sebagian besar responden berpendidikan D3, dan sebagian kecil responden berpendidikan $\mathrm{S} 1$. Pendidikan berarti bimbingan yang diberikan oleh seseorang kepada orang lain agar mereka dapat memahami. Tidak dapat dipungkiri bahwa makin tinggi pendidikan seseorang maka makin mudah pula bagi mereka untuk menerima informasi, dan pada akhirnya makin banyak pula pengetahuan yang mereka miliki. Kriteria responden berdasarkan lama kerja. Dari 35 responden yang diteliti, 14 orang atau $40.0 \%$ telah bekerja selama 1-5 tahun, dan21orangatau60.0\%telahbekerjaselamalebih dari 5 tahun. Hal ini menunjukkan bahwa sebagian besar responden telah lebih dari 5 tahun bekerja mengabdikan diri di RSUD Jayapura. Masa kerja berhubungan juga dengan pengalaman kerja diaman pengalaman adalah suatu kejadian yang pernah dialami oleh individu baik dari dalam dirinya ataupun dari lingkungannya.Pada dasarnya pengalaman 
mungkin saja menyenangkan atau tidak menyenangkan bagi individu yang melekat menjadi pengetahuan pada individu secara subjektif (Notoatmodjo, 2010).

Pada tabel 5 di atas menggambarkan pengetahuan perawat. Dari 35 responden yang diteliti, 33 orang atau $94.3 \%$ memiliki pengetahuan baik, 1 orang atau $2.9 \%$ memiliki pengetahuan cukup, dan 1 ora kurang. Hal ini menunjukkan bahwa hampir seluruh responden memiliki pengetahuan baik, sedangkan hanya sebagian kecil perawat yang memiliki pengetahuan cukup dan kurang. Hal ini berhubungan juga dengan tingkat pendidikan dimana dikatakan bahwa apabila seseorang memiliki tingkat pendidikan yang tinggi maka orang tersebut akan memiliki tingkat pengetahuan yang tinggi atau baik. dalam hal ini hampir rata-rata perawat tersebut memiliki tingkat pendidikan D3 walaupun ada juga yang memiliki tingkat pendidikan S1 tetapi pengalaman lama kerja yang membuat perawat D3 memiliki pengetahuna yang baik.

Pada tabel 6 di atas menggambarkan kepatuhan perawat dalam mencuci tangan. Dari

35 responden yang diteliti, 34 orang atau $97.1 \%$ patuh, dan 1 orang atau $2.9 \%$ tidak patuh. Hasil ini menunjukkan bahwa hampir seluruh responden patuh dalam melakukan pencegahan infeksi nosokomial. Kepatuhan seseorang dipengaruhi oleh kebiasaan dan budaya. Bisa dilihat dari beberapa contoh yaitu perawat yang sudah membiasakan diri sebelum melakukan tindakan harus melakukan mencuci tangan bersih apabila ini dilakukan terus menerus tanpa ada paksaan akan menjadi suatu kebiasaan atau budaya pada dirinya untuk melakukan mencuci tangan hal ini disebabkan karena perawat tersebut mengetahui tentang pentingnya mencuci tangan untuk mencegah terjadinya infeksi nosokomial.

2. Analisa Bivariat

Dari tabel 7 diketahui hasil analisis korelasi Spearman memiliki nilai rs $=0.717$, hal ini menunjukkan adanya keeratan hubungan antara pengetahuan perawat dengan kepatuhan. Tanda positif pada nilai rs menunjukkan bahwa pola hubungan linier, artinya semakin meningkat pengetahuan perawat akan disertai dengan meningkatnya kepatuhan. Nilai Sig. $(2-\quad$ tailed $)=0.000$ menunjukkan adanya kemaknaan hubungan antara dua variabel tersebut.

Hal ini dapat dilihat dari tingkat pendidikan dimana dikatakan bahwa apabila seseorang memiliki tingkat pendidikan yang tinggi maka orang tersebut akan memiliki tingkat pengetahuan yang tinggi atau baik, sedangkan untuk kepatuhan seseorang dipengaruhi oleh kebiasaan dan budaya. Dalam penelitian ini didapatkan hubungan antara pengetahuan dengan kepatuhan mencuci tangan sesuai dengan standar operasional prosedur yang ada di rumah sakit umum Jayapura.

Standar operasional prosedur yang dikenal dengan sebutan SOP merupakan salah satu acuan atau aturan yang harus di lakukan perawat dalam melakukan sesuatu tindakan, dalam mencuci tangan pun sudah ada standar operasional prosedurnya. Sehingga hal ini merupakan suatu prosedur yang harus dilaksanakan, hal serupa yang harus dilaksanakan sesuai prosedur adalah bagaimana seorang perawat dapat melakukan cuci tangan sesuai standar operasional prosedur.

Pengetahuan merupakan hasil dari tahu dimana dapat diartikan bahwa apabila seorang perawat memiliki pengetahuan yang baik tentang mencuci tangan maka kepatuhan untuk melakukan cuci tangan akan baik. Cuci tangan merupakan suatu tindakan kecil yang harus dilakukan sesudah dan sebelum melakukan tindakan keperawatan, akan tetapi perawat masih sangat jarang melakukannya dengan alasan lupa. Mencuci tangan adalah membersihkan tangan dari segala kotoran, dimulai dari ujung jari sampai siku dan lengan dengan cara tertentu sesuai kebutuhan.

Perilaku cuci tangan adalah salah satu bentuk kebersihan diri yang penting. Mencuci tangan juga dapat diartikan menggosok dengan sabun secara. bersama seluruh kulit permukaan tangan dengan kuat dan ringkas yang kemudian dibilas di bawah air yang mengalir (Linda dkk, 2010).

Hal ini sejalan dengan hasil penelitian yang dilakukan oleh Menurut Saefudin, et.al. (2010), tingkat kepatuhan untuk melakukan KU (Kewaspadaan Universal), khususnya berkaitan dengan HIV/AIDS, dipengaruhi oleh faktor individu (jenis 
kelamin, jenis pekerjaan, profesi, lama kerja dan tingkat pendidikan), faktor psikososial (sikap terhadap HIV dan virus hepatitis B, ketegangan dalam suasana kerja, rasa takut dan persepsi terhadap resiko), dan faktor organisasi manajemen (adanya kesepakatan untuk membuat suasana lingkungan kerja yang aman, adanya ng atau $2.9 \%$ memiliki pengetahuan dukungan dari rekan kerja dan adanya pelatihan), selain itu ada beberapa ahli sebagaimana dikemukakan oleh Smet (2010), mengatakan bahwa kepatuhan dipengaruhi oleh faktor internal dan factor eksternal. Faktor internal yang mempengaruhi kepatuhan dapat berupa tidak lain merupakan karakteristik perawat itu sendiri.

Sedangkan ada beberapa faktor-faktor yang berhubungan dengan tingkat kepatuhan perawat dalam mencuci tangan sesuai dengan hasil penelitian yang dilakukan oleh Lankford, et al (2013) bahwa faktor yang berpengaruh pada tindakan cuci tangan adalah tidak tersedianya tempat cuci tangan, waktu yang digunakan untuk cuci tangan, kondisi pasien, efek bahan cuci tangan terhadap kulit dan kurangnya pengetahuan terhada standar. Sementara itu Tuhamik (2013) menemukan dalam penelitiannya bahwa kurang kesadaran perawat dan fasilitas menyebabkan kurang patuhnya perawat untuk cuci tangan. Kepatuhan cuci tangan juga dipengaruhi oleh tempat tugas.

Dari hasil penelitian tersebut yang dapat penulis sampaikan yaitu apabila tingkat pengetahuan perawat terhadap cara mencuci tangan baik maka akan dengan sendirinya kepatuhan terhadap cuci tangan akan baik seperti dapat dilihat apabila seorang perawat memiliki pengetahuan yang baik tentang cuci tangan dan juga memiliki kepatuhan yang baik terhadap cuci tangan makan kegiatan tersebut akan berjalan dengan baik dan tidak akan lagi diketemukan keterangan perawat yang mengatakan bahwa lupa mencuci tangan selain itu juga apabila tingkat kepatuhan dalam mencuci tangan itu bagus kemungkinan kecil pasien terkena infeksi nosokomialrendah.Sehingga baik itu pasien atau perawat resiko terkena infeksi nosokomial akan rendah. Selain itu juga apabila seorang perawat telah memiliki kesadaran akan kepatuhan mencuci tangan tanpa harus diingatkan lagi perawat tersebut akan terbiasa melakukan cuci tangan.

\section{KESIMPULAN}

1. Dari hasil penelitian diketahui 35 responden diantaranya memiliki karakteristik pengetahuan baik 33 orang (94.3\%), pengetahuan cukup 1 orang (2.9\%) dan pengetahuan kurang 1 orang $(2.9 \%)$.

2. Dari hasil penelitian diketahui 35 responden diantaranya memiliki karakteristik kepatuhan perawat dalam mencuci tangan diketahui yang patuh 34 orang $(97.1 \%)$ dan yang tidak patuh 1 orang (2.9\%), hasil ini menunjukkan bahwa hamper seluruh responden patuh dalam melakukan pencegahan infeksi nasokomial dengan cara mencuci tangan.

3. Dari uji korelasi Spearman didapatkan nilai $r_{s}=0.717$, yang berarti ada keeratan hubungan sangat kuat antara pengetahuan perawat dengan mencuci tangan.

4. Standar operasional prosedur yang dikenal dengan sebutan SOP merupakan salah satu acuan atau aturan yang harus di lakukan perawat dalam melakukan sesuatu tindakan, dalam mencuci tangan pun sudah ada standar operasional prosedurnya. Sehingga hal ini merupakan suatu prosedur yang harus dilaksanakan, hal serupa yang harus dilaksanakan sesuai prosedur adalah bagaimana seorang perawat

\section{DAFTAR PUSTAKA}

Tietjan. (2010). Panduan Pencegahan Infeksi untuk Fasilitas Pelayanan Kesehatan dengan Sumber Daya Terbatas. Jakarta: YBP Sarwono Prawiroharjo.

Puspasari. (2015). Infeksi Nosokomial: Problematika dan Pengendaliannya. Jakarta: Salemba Medika. 123-126

Depkes RI. (2010). Pedoman Manajerial Pencegahan dan Pengendalian Infeksi di Rumah Sakit dan Fasilitas Pelayanan Kesehatan Lainnya. Jakarta: Departemen Kesehatan RI.

Mani, dkk (2010). Panduan Pencegahan Infeksi untuk Fasilitas Pelayanan Kesehatan dengan Sumber Daya Terbatas. Jakarta: ECG

Saragih \& Rumpea. (2010). Faktor- faktor 
yang berhubungan dengan perawat dan bidan dalam penerapan kewaspadaan universal standar di rumah sakit. Bogor: Rineka Cipta

Sari. (2017). Perilaku Perawat terhadap Infeksi Nososkomial. Yogyakarta, penerbit Nuha Medika

Notoatmojo. (2010). Metode penelitian kesehatan

(edisi revisi). Jakarta : Rineka Cipta.

Septiari. (2012). Infeksi Nosokomial. Jakarta: Nuha Medika.

WHO. (2012). Hand Hygiene in Outpatient and Home-Based Care and Long-term Care Facilities. Switzerland: Geneva.

Linda, dkk (2010). Analisis Data Kinerja Perawat Dalam Pengendalian Infeksi Nosokomial Di Ruang IRNA I RSUP Dr. Srdjito Yogyakarta
Saefudin et al. (2010). Kemampuan Perawat Terhadap Pencegahan Infeksi Nosokomial Pada Pasien Dengan pemasangan kateter BPK RSU Dr. Zainoel Abidin. PSIK FK Unsyiah Banda Aceh.

Lankford et al. (2013). Universal Standard infection Control Policy Royal United Hospital Vath. www.ryh.nhs.uk. Diakses pada tanggal 10 Januari 2017, jam 12.30 WIT.

Tuhamik. (2013). Dasar-dasar patologi yang berhubungan dengan pengetahuan infeksi nososkomialpadaperawat.Jakarta:Pe nerbitBukuKedokteran 